\title{
Supervision of Foundation Management Based on Law Number 28 of 2004 Concerning Foundations*
}

\author{
Heru Subandono Notonegoro ${ }^{1}$ \\ Doctoral Program at Sebelas Maret University, Surakarta Indonesia \\ doi $10.15408 /$ sjsbs.v5i3.10339
}

\begin{abstract}
.
This research aims to investigate the issue of supervision of foundation management based on Law No. 28 of 2004 concerning Foundations. By using normative methods, conclusion is drawn that the supervisory arrangement as regulated in Law No. 28 of 2004 concerning Foundations adopts internal and external supervisions, which govern the authority of supervisors in conducting supervision. Internal supervision of a foundation is handed to the supervisor as one of the organs of the foundation. Duties and powers of the internal supervisory organ includes the duties and authorities of the internal supervisory organ in managing the foundation. External supervision is a form of supervision by parties, which coordinate directly or indirectly to the Ministry of Law and Human Rights as the parent of community organizations.
\end{abstract}

Keywords: Foundation, supervision, management

\begin{abstract}
Abstrak.
Penelitian ini bertujuan untuk mengetahui permasalahan pengawasan pengelolaan yayasan berdasarkan Undang-Undang Yayasan Nomor 28 Tahun 2004. Dengan menggunakan metode normatif, dapat disimpulkan bahwa pengaturan pengawasan dalam Undang-Undang Yayasan Nomor 28 Tahun 2004 menganut sistem pengawasan internal dan eksternal yang mengatur kewenangan pengawas dalam melakukan pengawasan. Pengawasan internal dalam yayasan diserahkan kepada pengawas sebagai salah satu organ yayasan. Tugas dan wewenang dari pengawas internal mencakup tugas dan wewenang organ pengawas yayasan dalam mengelola yayasan. Pengawasan eksternal merupakan bentuk pengawasan yang dilakukan oleh pihak yang memiliki garis koordinasi secara langsung atau tidak langsung dalam organisasi Departemen Hukum dan Hak Asasi Manusia sebagai induk dari organisasi kemasyarakatan.
\end{abstract}

Kata kunci: Yayasan, Pengawasan, Pengelolaan

${ }^{*}$ Diterima: 22 September 2018, Revisi: 23 Oktober 2018, Dipublikasi 31 Desember 2018.

1 Heru Subandono Notonegoro is a Student of Doctoral Program at Sebelas Maret University, Surakarta Indonesia. E-mail: heru.subandono@gmail.com. 


\section{Introduction}

A foundation, as a social, religious, and humanitarian legal body, has organs comprising steering committee, organizing committee, and supervisory committee. A clear separation of functions, powers, and duties of each organ is meant to avoid the possibilities of internal conflict which can harm the foundation's interest and other parties related to the foundation's activities. The management of foundation's assets and activities is fully conducted by the organizing committee. Therefore, the organizing committee must present annual report to the steering committee on the foundation's financial statement and improvement of activities.

There are many reasons why foundations deviate from their philosophical founding intention. In the society, there exist many foundations conducting activities of trade in which the founding intents and purposes are contradictory to the founding intents and purposes of the foundation. This problem is caused by, among other reasons, the difficulty in defining what is meant by "social activities". Academic foundations, for example, which fall under social activities category, in reality are often used to gain so much profit that it is often said that quality education comes expensively. Other parties provide argumentation that even though there is no regulation prohibiting foundations to conduct business activities, it should be remembered that in its essence, foundations are not profitoriented, but social-oriented.

Based on the aforementioned issues, this research intends to study further the supervision of foundation management based on Law No. 28 of 2004 regarding Foundations.

\section{Methods}

This research used the normative, prescriptive research with legislation approach. The research used secondary data comprising: firstly, primary legal source, such as Law No. 28 of 2004 concerning Foundations; secondly, secondary legal sources, consisting of books, legal dictionaries, journals on Law Science, and scientific works, as well as researches relevant to this research including undergraduate thesis, thesis, dissertation, magazines, and articles on law.

The data of the research were collected through library research by reading and studying books, legislations, writings, and scientific publications related to supervision of foundation management. The legal sources were analyzed by using the deductive method.

\section{Result and Discussion}

Point (1), Article 1 of Law No. 28 of 2004 concerning Foundations states: 
"A foundation is a legal body which consists of separated assets and intended to achieve certain goal in social, religious, or humanitarian field, which does not have any member."

It is perceived from the definition above that a foundation becomes a legal body because of the Law, or based on Law, not based on customs, doctrines, or jurisprudence. The most prominent characteristic of a legal body is its immunity in accountability, meaning that by obtaining legal body status, the said legal body is responsible to itself regardless of the humans involved in it, solely and only limited to the assets it owns.

To put it simply, a legal body is an organization or association founded by authentic certificate and considered as a subject of law in which rights and responsibilities are attached to it. $^{2}$

A foundation is considered as a subject of law because it fulfills certain things: a foundation is an association of people; a foundation can conduct acts of law in legal relation; a foundation has its own assets; a foundation has its own organizing committee; a foundation has intents and purposes; a foundation has an legal position (address) of place; and a foundation can be sued, and can file a suit to the Court. The elements mentioned above can conclude that foundation fulfills terms as a legal body.

In theoretical perspective, law science recognizes the existence of Theory of Intended Assets (Teori Kekayaan Bertujuan). According to this theory, only humans can be subject of law. However, it is an unarguable truth that there exist rights to wealth while there is no human which becomes the supporter of those rights, and that the rights of a legal body is actually rights which no one owns, and as a substitute the rights become assets bonded by an intention, or assets owned for certain goal. This theory of law becomes a basis of existence of foundation as a legal body. ${ }^{3}$

System of supervision of foundation in Indonesia is based on Law No. 28 of 2004 regarding Amendment to Law No. 16 of 2001 concerning Foundations, and further regulated in State Regulation No. 63 of 2008 concerning Foundation.

\section{Foundation Law Puts Forward Good Governance}

Law No. 28 of 2004 concerning Foundations is based on the principles of good governance, which are transparency and accountability, visible in the foundation's openness on annual reports. Article 52, Law No. 28 of 2004 concerning Foundations apparently states that:

\footnotetext{
2 Pujiyono, Hukum Perusahaan, (Surakarta: Pustaka Hanif, 2014), 40.

${ }^{3}$ Chatamarrasjid Ais, Badan Hukum Yayasan, Edisi Revisi, (Bandung: Citra Aditya Bakti, 2006), p.41.
} 
(1) "Summary of the foundation's annual report is announced on announcement board in the foundation's office.

(2) Summary of financial statement which is a part of annual report summary as stated in point (1), must be announced in daily newspaper in Indonesian, for foundations which:

(a) receive State allowance, foreign endowment, and/or contribution from others amounting to Rp500,000,000.00 (five million rupiahs) or more, in one book year; or

(b) have assets outside religious donation assets amounting to Rp20,000,000,000.00 (twenty billion rupiahs) or more.

(3) The foundation's financial statement as stated in point (2) should be audited by public accountant.

(4) The auditing result to the foundation's financial statement as stated in point (3) is reported to the foundation's steering committee and forwarded to Minister of Law and Human Rights and related institutions."

Conditions in this article are intended to let people know about donations received by foundations, or foundations having certain amount of assets, in accordance with the principles of transparency and accountability.

Transparency in foundation management at least consists of two things, namely: announcement in the Supplement to State Gazette about the foundation's Articles, and annual report announcement. In this case, the consequences received by foundations as legal bodies are by the existence of announcement in the supplement to State Gazette, the people can access information about them, while by the annual report announcement, the people can obtain information related to the foundation's condition, activities, and financial statement, which consists of the end-of-period financial position, reports of activity, reports of treasury flow, and documentation of financial statement. Also, if the foundation conducts transaction to other parties which creates rights and responsibilities to the foundation, the transaction should be included in annual statement.

Annual reports as an application of transparency and accountability principles are very important to prevent misappropriation of the institution of foundation. A clearer regulation is therefore needed to state the effects to foundations if they neglect this responsibility. This legislation also does not regulate which type of foundation which should prepare and announce annual report, meaning that every foundation, regardless of their types, should prepare and announce annual report. In the future, it needs to be considered whether there are exceptions to certain types of foundations, such as those owning a relatively small amount of assets. Even so, although the annual report is compulsory by nature, no legal sanctions for the evaders. The sanction regulated in this law is only related to the prohibition of transfer of foundation's assets, which is punishable by 
five-year prison sentence, while no legal sanction to violation or neglect to other responsibilities, including preparing and announcing annual reports was found on the Foundation Law.

\section{Supervision in Law No. 28 of 2004 concerning Foundations}

Supervision is aimed at correcting mistakes that happened, which later can be used as guidance in making policies to achieve optimum results. The aim of supervision of foundation management based on Law No. 28 of 2004 concerning Foundations is to restore functions of a foundation as a legal institution in order to achieve certain goal in social, religious, and humanitarian field based on principles of transparency and accountability.

The function of foundation management supervision is to prevent corruption, deviation, divergence, and neglect conducted by the foundation organs in order for unintended loss to not happen. The supervisory arrangements as regulated in Law No. 28 of 2004 concerning Foundation adopts internal and external supervision which govern the authority of supervisors in conducting supervision.

\section{a. Internal supervision}

Internal supervision is accommodated by the existence of supervisory function exercised by supervisory organ. The existence of supervisor is intended to control organizing committee in conducting its activities with accountability and not harming the foundation. When the organizing committee conducts action in contravention to foundation's articles or State legislations, Supervisor has the power to dismiss the organizing committee temporarily as stated in Article 43 of Foundation Law.

Duties and responsibilities of internal supervisor itself consist of the duties and responsibilities of supervisory organ in managing the foundation:

1) Supervisor has rights to conduct investigations on the foundation's financial documents. It is therefore appropriate to appoint a person with skills and experience in financial accounting in order to supervise good conduct of foundation management.

2) Supervisor has rights to know all actions conducted by organizing committee and give warning to the organizing committee.

3) Supervisor has power to temporarily dismiss organizing committee, if the organizing committee is found to act in direct contravention to the prevailing foundation's Articles and State Legislations.

4) Supervisor should perform his/her duties in good faith and full responsibility for the foundation's interests. 
5) During temporary dismissal of organizing committee, Supervisor should take care of the foundation.

Law No. 28 of 2004 concerning Foundations regulates personal responsibility of supervisor as same as to the organizing committee, as stated in Article 42 of Foundation Law, which reads as follows. "Supervisor should perform his/her duties in good faith and full responsibility for the foundation's interests."

Supervisor with their self-awareness should always perform their characteristic of duties and position in the foundation, which is to supervise the organizing committee's performance, because if the organizing committee in performing their duties conducts mistakes, especially when it causes damage to the foundation or third parties, then the supervisor should also be held responsible since they also made mistakes in letting the mistakes happen.

Mistakes by organizing committee can happen because of low supervision. Consequently, the supervisor also plays a role in this mistake, and it should have the same effect on them as on the organizing committee, in which the supervisor is personally held responsible. ${ }^{4}$

\section{b. External supervision}

External supervision is a form of supervision by parties which coordinate directly or indirectly to the Ministry of Law and Human Rights as the parent of community organizations. Observing the existing control mechanism forms and concepts in the existing legal and political system, there are three forms of external supervision to the performance of community organizations:

1) Legislative supervision

Legislative supervision is a form of supervision conducted by people's representative body to the wisdom and execution of general duties of government and development in accordance with its duties, powers, and rights.

Related to foundations, the People's Representative Council with the President makes Foundation Law and its further regulation in State Regulation and Ministry of Law and Human Rights. This is visible in point (1), Article 11 of Law No. 28 of 2004 concerning Foundations stating as follows: "A foundation obtains legal body status after its certificate foundation, as stated in point (2), Article 9, obtains legalization from the Minister."

\footnotetext{
${ }^{4}$ Gatot Supramono, Hukum Yayasan di Indonesia, (Jakarta: Rineka Cipta, 2008), 105.
} 
The Minister of Law and Human Rights has the power to issue decree to grant or deny the request of legalization of foundation's certificate of foundation and the certificate of foundation merger with the basis.

Financial Inspection Agency (BPK) also plays a role in relation to foundation, apparent in point (3), Article 52 of Law No. 28 of 2004 concerning Foundations which states that, "The foundation's financial statement as stated in point (2) should be audited by public accountant."

The Agency has powers to conduct financial auditing on the foundation in accordance with the prevailing legislation.

Legislative supervision function becomes not effective in facing deviation in foundation, since it only gives warnings or suggestions for improvement, added by the fact that binding sanctions from legislative body when the warnings and suggestions are not heeded are inexistent.

\section{2) Public supervision}

Public supervision is a form of supervision conducted by general public reported in written or oral form to the related government apparatus, berupa sumbangan pemikiran, saran, gagasan, or constructive complaints reported directly or through media.

Related to foundation, public supervision has the power of giving responsible suggestions and opinion in written or oral form in forms of ideas, suggestions, or constructive complaints reported directly or through media to the foundation about its performance to realize clean government conduct. There are two basic problems which becomes public supervision shortcomings:

a) Public supervision is often casuistic and partial in nature, and tends to address the issue of budget.

b) The inexistence of proper channel and mechanism to handle public supervision, and no patent guidance in handling it, which causes data and information about factual condition to be hard to obtain, while the success of socialization is determined by optimal support power and community participation characterized by the existence of social control and social support. $^{5}$

For public supervision of the foundation's performance, Foundation Law regulates organizing committee to announce the summary of its annual report in the respective foundation's office, so that the people can read it. For such foundations which assets comes from the State, or receive government allowance,

${ }^{5}$ Didin Sudirman, Reposisi dan Revitalisasi Pemasyarakatan dalam Sistem Peradilan Pidana di Indonesia, (Jakarta: Alnindra Dunia Perkasa, 2007), h.7. 
or such foundations which assets are gathered from public funds such as donations, religious donations (waqf), grants, and testament grants, which causes the foundation to have certain amount of wealth (regulated in State Regulation), they should announce summary of their annual report in Indonesian-language daily newspaper stated in point (1), Article 52 of Law No. 28 of 2004 concerning Foundations which states: "Summary of the foundation's annual report is announced on announcement board in the foundation's office."

3) Supervision by supervisory and observation justice

Supervision by supervisory and observation justice is a supervision conducted by a justice specially designated by District Court chairman to conduct supervision and observation to the execution of court ruling.

Related to supervision of foundation, supervision by supervisory justice is materialized in the act of supervisory and observation justice inspecting and signing register of supervision and observation in District Court clerkship in terms of foundation and its organ which conducts acts against the law. External supervision is conducted based on an appeal by third parties, or by request filed by Prosecutor's Office representing public interest.

According to point (1), Article 53 of Foundation Law which states that,

"Investigation to foundation to obtain data or information is able to be conducted should there arise any allegation that the foundation organ

(a) conducts acts against the law or acts against articles of the foundation;

(b) neglects its duties and responsibilities;

(c) conducts acts harming the foundation or third parties; or

(d) conducts acts against the State.",

The parties conducting investigation are several experts appointed by court ruling. These investigators are not announced or inform their results of investigation to other parties except the Chairman of the District Court in the foundation's place of location.

\section{Supervisory Processes in Law No. 28 of 2004 concerning Foundations}

Supervision on foundations is commenced from its initial foundation, especially in preventing the foundation to be used as a means of conducting activities of trade for profit and foundation-masked fraud. This is accommodated by conditions in Foundation Law about the responsibility of documenting the foundation's foundation in authentic certificate, accompanied by its legalization and registration to the Minister of Law and Human Rights, as stated in point (1), 
Article 11 of Law No. 28 of 2004 concerning Foundations which reads as follows: "A foundation obtains legal body status after its certificate foundation, as stated in point (2), Article 9, obtains legalization from the Minister."

The legalization function is intended for the legality of a legal body's existence so that it has suitability, meaning the degree of compatibility with prevailing legislations, especially legislation on foundations. This formulation brings a consequence, in which as a legal body, a foundation should have characteristics and ability to act like a subject of law. ${ }^{6}$

Subsequently, in terms of good governance application in management of foundations, one should concern about the investigation of foundations. Related to this, point (1), Article 53 of Foundation Law states as follows:

"Investigation to foundation to obtain data or information is able to be conducted should there arise any allegation that the foundation organ

(a) conducts acts against the law or acts against articles of the foundation;

(b) neglects its duties and responsibilities;

(c) conducts acts harming the foundation or third parties; or

(d) conducts acts against the State."

Procedures in conducting investigation are further regulated in point (2), Article 53 of Foundation Law which states: "Investigation as stated in point (1), letter $(a),(b)$, and (c) can only be conducted based on court ruling to written appeal by a related third party provided with basis of appeal."

The condition provides that investigation can only be conducted based on court ruling to written appeal by a related third party provided with basis of appeal. Prosecutor's Office can file an appeal of investigation representing public interest.

The court can grant or deny the appeal of investigation. If the appeal is granted, the court will then issue a ruling of investigation and appoint a maximum of three experts as investigators. The object of investigation itself is all of the foundation's documents and assets. All documents and result of investigation are not allowed to be announced or informed to other parties. Investigation result must be reported to the Chairman of District Court, and then the Chairman gives copies of investigation result to the petitioner and the respective foundation.

There are two natures and periods of supervision as provided in Law No. 28 of 2004 concerning Foundations:

\footnotetext{
${ }^{6}$ Gunawan Widjaja, Yayasan di Indonesia Suatu Panduan Komprehensif, (Jakarta: Elex Media Komputindo, 2002), p.2.
} 


\section{a. Preventive control}

Preventive control is a control exercised before foundation activities were conducted to avoid deviations in their execution. It is stated on conditions in Article 13A of Foundation Law, which reads as follows: "Before a foundation obtains legal body status, the foundation's organizing committee is responsible in its entirety to legal actions conducted on behalf of the foundation."This makes the organ managing the foundation has full responsibility in order to save it from deviations.

\section{b. Repressive control}

Repressive control is a form of control conducted after mistakes were made in the foundation's execution of activities intended to prevent repetition of similar mistakes in the future, in order to achieve the intended results. It is found in the conditions in Article 13A of Foundation Law which reads as follows: "Before a foundation obtains legal body status, the foundation's organizing committee is responsible in its entirety to legal actions conducted on behalf of the foundation."

Article 25 of Foundation Law: "As long as such announcements as stated in Article 24 are not made, the foundation's organizing committee is responsible in its entirety to the foundation's losses." This makes the organ managing the foundation has full responsibility in order to save it from deviations.

\section{Conclusion}

Until presently, legislation on foundations still becomes one of the factors of bad foundation management. It is because some Articles or conditions provided in the Foundation Law are still vague, creating various sets of interpretation. Arrangements of supervision provided in Law No. 28 of 2004 concerning Foundations adopts internal and external supervision which govern the authority of supervisors in conducting supervision. Internal supervision in the foundation is handed to the supervisor as one of the organs of the foundation. Duties and powers of the internal supervisory organ includes the duties and authority of the internal supervisory organ in managing the foundation. External supervision is a form of supervision by parties which coordinate directly or indirectly to the Ministry of Law and Human Rights as the parent of community organizations.

\section{Suggestions}

Foundation Law should evaluate the existence of supervisory organ of foundations to strengthen its position, by recommending it to be kept or dismantled from structure of organization. It is far better if this supervisory 
function is handed to a body or agency which can represent public interest, such as Prosecutor's Office or Ministry of Law and Human Rights.

It is necessary to regulate amendments to Foundation Law related to the legal effect of a foundation which conducts capital attachment that exceeds maximum limit, in terms of founding and/or putting joint effort in a badan usaha, as regulated by the Law, in order for the conditions for a foundation to be permitted to conduct activities of trade by founding and/or putting joint effort in a prospective badan usaha, not to be a regulation which loses its force of compulsion which can easily be evaded by foundations.

\section{References}

\section{Books}

Ais, Chatamarrasjid. 2006. Badan Hukum Yayasan Edisi Revisi. Bandung: Citra Aditya Bakti.

Aji, Ahmad Mukri. Urgensi Maslahat Mursalah Dalam Dialektika Pemikiran Hukum Islam, Bogor: Pustaka Pena Ilahi, 2012.

Kusumastuti, Arie. 2002. Hukum Yayasan di Indonesia. Jakarta: Center Publishing.

M, Rita. 2009. Risiko Hukum Bagi Pembina, Pengawas dan Pengurus Yayasan. Jakarta: Forum Sahabat.

Margono, Suyud. 2001. Hukum Yayasan Dilema Tujuan Karitatif atau Komersial. Jakarta: Novindo Pustaka Mandiri.

Mulhadi. 2010. Hukum Perusahaan, Bentuk-Bentuk Badan Usaha di Indonesia. Bogor: Ghalia Indonesia.

Murjiyanto. 2011. Badan Hukum Yayasan (Aspek Pendirian dan Tanggungjawab). Yogyakarta: Liberty.

Prasetya, Rudhi. 2012. Yayasan Dalam Teori dan Praktik. Jakarta: Sinar Grafika.

Pujiyono. 2014. Hukum Perusahaan.Surakarta: Pustaka Hanif.

Rido, Ali. 2004. Badan Hukum dan Kedudukan Badan Hukum Perseroan, Perkumpulan, Koperasi, Yayasan, Wakaf. Jakarta: Alumni.

Supramono, Gatot. 2008. Hukum Yayasan di Indonesia.Jakarta: Rineka Cipta.

Widjaja, Gunawan. 2002. Yayasan di Indonesia Suatu Panduan Komprehensif. Jakarta: Elex Media Komputindo.

Yunus, Nur Rohim. Restorasi Budaya Hukum Masyarakat Indonesia, Bogor: Jurisprudence Press, 2012. 


\section{Journal articles}

Angeline. 2013. "Penyalahgunaan Kewenangan Pengurus Dalam Pengelolaan

Badan Hukum Yayasan Di Indonesia". Jurnal RechtsVinding. Vol 1 No. 2, Agustus 2012. Surabaya: Unair Press.

Muhammadin, Fajri Matahati. "The GPH-MILF Agreement: Human Rights Provisions and Possible Overlaps," Jurnal Cita Hukum, Volume 2 No. 1 (2014).

No. 1, April 2006. USA: Harvard University

Private Foundation". Harvard Journal of Law and Public Policy. Vol 30

Schramm, Carl J. 2006. “Law Outside The Market: The Social Utility Of The

Simamora, Yohanes Sogar. 2012. "Karakteristik, Pengelolaan Dan Pemeriksaan

van der Walt, AJ. 2014. "The Modest Systemic Status of Property Rights". Journal of Law, Property, and Society. Vol 1 No. 2, November 2014. Widener University School of Law.

Yayasan Menurut Undang-Undang Nomor 16 Tahun 2001 jo. Undang-Undang Nomor 28 Tahun 2004". Transparency Jurnal Hukum Ekonomi. Vol 2 No. 1, Juni 2013. Medan: USU Press.

Yunus, Nur Rohim., Sholeh, Muhammad., Susiolawati, Ida. "Rekontruksi Teori Partisipasi Politik Dalam Diskursus Pemikiran Politik Negara" dalam Salam; Jurnal Sosial dan Budaya Syar-i, Vol. 4, No. 3 (2017).

\section{Legislations}

Law No. 16 of 2001 on Foundations.

Law No. 28 of 2004 concerning Amendments to Law No. 16 of 2001 on Foundations. 